Editorial

\title{
Reconocimiento a nuestros revisores
}

\section{Acknowledging our Reviewers}

\author{
Andrés Kohan ${ }^{1}$ \\ ${ }^{1}$ Editor Responsable, Revista Argentina de Radiología, Buenos Aires, \\ Argentina
}

Rev Argent Radiol 2019;83:1-2.

La revisión por pares es, para muchos, lo que la democracia era para Winston Churchill: el peor de todos los sistemas, con excepción de todos los demás.

Aquellos que se oponen al sistema lo acusan de tardar mucho, de ser sesgado e inconsistente. ${ }^{1,2}$ También señalan que no existe evidencia que avale el uso de ese sistema., Para ser justos, también deberíamos agregar al sesgo del revisor aquel que introducimos quienes elegimos a los revisores. Aunque ustedes no lo piensen, nosotros los conocemos y muchas veces prevemos cuánto y cómo nos pueden ayudar en la evaluación de un trabajo.

Por otro lado, quienes apoyan el uso de ese sistema creen que, a pesar de sus limitaciones, es la mejor forma de conseguir contenido original, artículos metodológicamente correctos y libres de mala conducta científica. ${ }^{2}$ Sin embargo, eso último es cuestionable: se encuentran numerosos ejemplos de artículos o líneas completas de investigación que debieron ser retiradas porque resultaron ser más ciencia ficción que ciencia.

Otro aspecto muy discutido en el ambiente editorial tiene que ver con cómo reconocer el trabajo del revisor. Se ha calculado que revisar la literatura pertinente, el artículo en cuestión y hacer comentarios lleva en promedio tres horas a un revisor experimentado. ${ }^{1}$ No es poco tiempo, si se considera que los revisores experimentados suelen estar en varias bases de revisores para varios journals y pueden revisar hasta cinco artículos por semana. ${ }^{1}$ Algunos journals han elegido reconocer las revisiones de calidad mediante el pago de honorarios. Otros, pertenecientes a grandes editoriales, mediante descuentos en la compra de material educativo de esa editorial. Finalmente están los que otorgan reconocimiento certificado para poder plasmarlo en un $\mathrm{CV}$ o, aún mejor, otorgan puntaje CME para la recertificación. En ese punto, vale comentar que desde hace menos de dos años existe una plataforma (www.publons.com) que permite a los revisores llevar un registro de las revisiones ya hechas, con el objeto de poder incluirlas como mérito académico al momento de postularse a trabajos, becas $\mathrm{y}$ otros reconocimientos.

Address for correspondence Andrés Kohan, Editor

Responsable, Revista Argentina de Radiología, Buenos Aires, Argentina (e-mail: andres.a. kohan@gmail.com).
En la Revista Argentina de Radiología (RAR), creemos fervientemente que solo podremos llegar hasta donde nuestros revisores nos lleven. Solo lograremos la visibilidad que ellos nos ayuden a obtener. Con eso en mente, hemos conseguido que el trabajo del revisor pueda otorgar puntaje para la recertificación del Consejo Argentino de Evaluación en Diagnóstico por Imágenes (CONAEDI).

Ese cambio, que consideramos será para bien, exige que realicemos otros. La entrega de puntaje nos obliga a estandarizar a quienes pueden acceder a ese puntaje. Nos obliga a ser críticos y evaluar, no solo qué revisor fue profundo y considerado y demostró pericia, sino también cuáles fallaron en alguna de esas características.

Desde que la revista se profesionalizó, con la contratación de Elsevier, los miembros del comité debíamos puntuar la labor del revisor. Luego, dicho puntaje se utilizaba para premiar a los mejores revisores durante el congreso argentino de diagnóstico por imágenes. De ahora en más, esa puntuación es la que nos guiará en cuanto a qué revisores podrán acceder a los créditos de recertificación y cuáles no.

Los criterios que seguiremos (-Tabla 1 ) fueron consensuados con las autoridades de la CONAEDI, con el fin de identificar verdaderamente a aquellos que cumplen con los pasos previamente detallados: revisar la literatura, revisar críticamente el trabajo y realizar comentarios.

Junto con esos cambios y aprovechando el nuevo rol que le asignamos a la puntuación que ya veníamos haciendo,

Tabla 1 Criterios para la obtención de puntaje de recertificación

1- El revisor debe tener mínimo dos revisiones con un puntaje $\geq 60$ (escala 1-100) en un año calendario

2- Luego de dos revisiones con puntaje $\geq 60$, cada nueva revisión con puntaje $\geq 60$ otorgará créditos adicionales de recertificación

Copyright (c) 2019, Sociedad Argentina de Radiología. Publicado por Thieme Revinter Publicações Ltda., Rio de Janeiro, Brazil. Todos los derechos reservados.

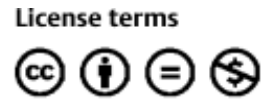

DOI https://doi.org/ 10.1055/s-0039-1685201. ISSN 1852-9992. 
utilizaremos esa información para mantener nuestra base de revisores actualizada y así agilizar los tiempos de revisión. Sucede que, en ocasiones, el proceso se demora por falta de respuesta a la invitación o demora en la devolución de las revisiones. De esa forma, podremos ofrecer a los autores la otra pata de este trípode sin el cual la revista no se puede sostener: una evaluación pertinente, superadora y oportuna. Al finalizar el año calendario, evaluaremos lo realizado por nuestros colaboradores y, aparte de otorgar certificados con el puntaje de recertificación obtenido, nos comunicaremos con aquellos revisores que tuvieron dificultades en su rol para evaluar conjuntamente si desean seguir recibiendo artículos y ayudando a la revista.
Sabemos que revisar artículos les roba tiempo de su trabajo, de su descanso o incluso de su familia. Por eso les estamos muy agradecidos y esperamos poder empezar a devolver un poco de aquello que tanto nos dan desinteresadamente.

Hasta el próximo número.

\section{Bibliografía}

1 Gasparyan AY, Gerasimov AN, Voronov AA, Kitas GD. Rewarding peer reviewers: maintaining the integrity of science communication. J Korean Med Sci 2015;30(04):360-364

2 Gasparyan AY, Kitas GD. Best peer reviewers and the quality of peer review in biomedical journals. Croat Med J 2012;53(04): 386-389 